\title{
Evaluation of Potato Cultivars Grown in Saudi Arabia by Morphological Characters and RAPD Markers
}

\author{
Abd-Rahman Mohamed M. Al-Moshileh*1, \\ Mohamed Zaky El-Shinawy ${ }^{2}$ and \\ Mohamed Ibrahim Motawei ${ }^{1}$
}

\author{
${ }^{1}$ Department of Plant Production and Protection, College of Agriculture and \\ Veterinary Medicine, Al-Qassim University, Saudi Arabia \\ ${ }^{2}$ Horticulture Department, Faculty of Agriculture, Ain Shams University, \\ Shobra El-Khima, Cairo, Egypt
}

\section{تقويم بعض أصناف البطاطس النامية في المنطقة الوسطى بالمملكة العربية السعودية باستخدام الصفات المورفولوجية و الالائل الجزيئية (RAPD)}

$$
\text { عبد الرحمن بن محمد المشيلح ، محمد زكى الثناوي ومحمد إبر اهيم مطاوع }
$$

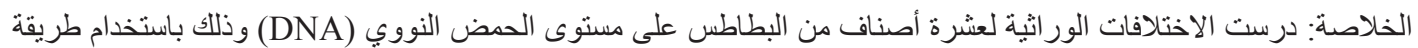

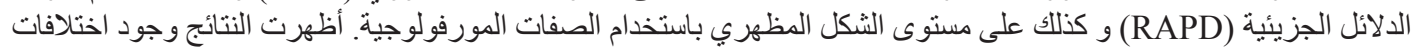

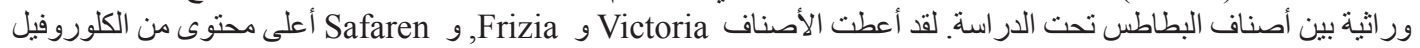

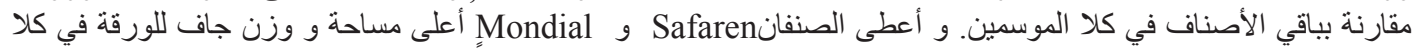

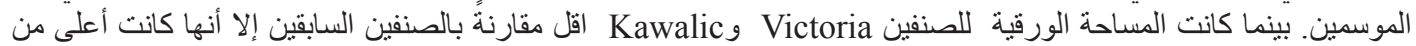

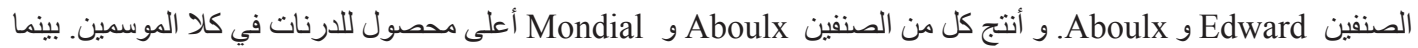
أنتج الصنفان Edward و Victoria و اقل محصول للارنات. و واختلفت الكثافة النو عية بين أصناف البطاطس المدروسة.

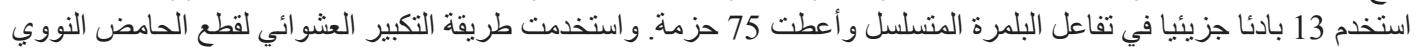

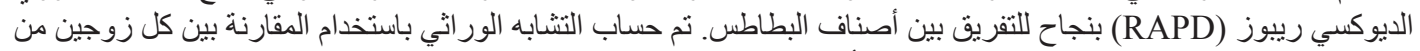

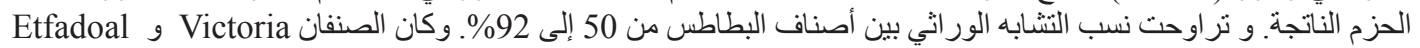

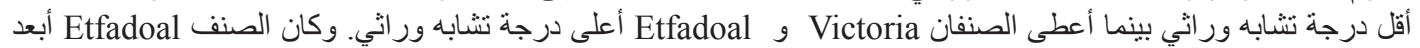

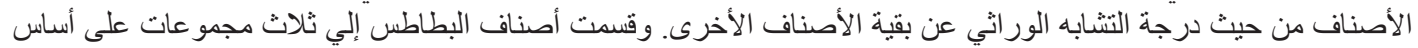

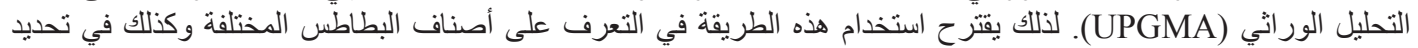
الصفات الاقتصادية الهامة في الخر ائط الور اثية لعشائر البطاطس.

ABSTRACT: Genetic diversity of 10 potato cultivars was investigated at the DNA level with the random amplified polymorphic DNA (RAPD) procedure and at the phenotypic level using morphological characters. The results indicated that there were considerable variations among the different studied cultivars. Cultivars Victoria, Frizia and Safaren had the highest chlorophyll content compared to the other cultivars in both seasons. The largest leaf area and leaf dry weight were measured in cultivar Safaren and Mondial in both seasons. Cultivars Aboulx and Mondia produced the highest tuber yield in both seasons. On the other hand, cultivars Victoria and Edward were characterized by their considerably lower yield than other studied cultivars. Specific gravity varied considerably among the different potato cultivars. Thirteen random decamer primers were used to amplify DNA via the polymerase chain reaction and 75 RAPDs were generated. The RAPD profiles obtained were successfully used to differentiate potato cultivars. Based on the pair-wise comparison of amplification products, genetic similarity was estimated. The genetic similarity among all potato cultivars ranged from 50 to $92 \%$. Cultivars Victoria and 
Etfadoal presented the least similarity (0.50) while cultivars Mondial and Citrix had the greatest similarity (0.92). Etfadoal cultivar displayed the greatest genetic diversity of all cultivars. A dendrogram was constructed using UPGMA analysis. On the basis of this analysis, the cultivars were grouped into three clusters. The polymorphism detected suggests that RAPD markers are reliable for identification of potato cultivars and could be exploited in genetic mapping of populations to tag economically important traits.

Keywords: Potato cultivars, fingerprint, genetic diversity, RAPD markers, morphological characters.

\section{Introduction}

Potato (Solanum tuberosum L.) is considered as one of the most important vegetable crops all over the world. Qassim region generates about half of the potatoes produced in Saudi Arabia (Zaag, 1991). The total production of potatoes in Saudi Arabia in 2002 was 315,000 tons (Ministry of Agriculture, 2004). Potato production can be affected by several environmental factors, such as moisture, temperature, day length, light intensity, nutrient availability and genetic variation.

The catalogue of potato varieties provides an indispensable source for obtaining optimum potato crops. Any new variety should comply with the strict requirements of growers and users. Therefore, information on the performance of varieties allows selection of the most suitable variety for any specific conditions and provides information on the latest developments in the field of potatoes (Coumou, 2000).

Identifying plant cultivars by molecular markers procedures is becoming a practical necessity (Smith and Smith, 1992). The relatively narrow range of morphological traits and limited numbers of polymorphic isoenzyme systems are not sufficient to discriminate all the cultivars of any given species. Furthermore, many phenotypic traits are developmentally regulated or influenced by the genotype $\mathrm{X}$ environment interaction. However, with the advent of DNA-based genetic markers, such as restriction fragment length polymorphisms (RFLP) and random amplified polymorphic DNAs (RAPD), the fingerprinting of plant cultivars has become more efficient, reliable, and useful (Caetano-Anolles et al., 1991 and Nybom, 1994).

RAPD markers have been used successfully to identify many useful polymorphisms quickly and efficiently, and therefore the method has potential for use in cultivar identification (Schneider and Douches, 1996). Also, RAPDs were shown to provide a level of resolution equivalent to RFLPs for determining genetic relationships among some cabbage (Brassica oleracea L.) genotypes (Dos Santos et al., 1994) and among B. napus L. breeding lines (Hallden et al., 1994). Estimates of genetic similarity based on RAPDs have been developed for Lycopersicon Miller (Williams and St. Clair, 1993), Allium cepa L. (Wilkie et al., 1993), and Solanum tuberosum L. (Rocha et al., 2002 and Collares et al., 2004). RAPDs have been used to investigate developmental variation in micropropagated potatoes (Joyce et al., 1999) and also to correlate genetic variation observed in natural wild potato populations in the USA with a series of different ecological, geographical and reproductive variables (del Rio et al., 2001).

Farmers and agricultural companies in Saudi Arabia use mainly imported potato seeds from Europe. Therefore, it is important to have evaluation and identification studies for potato cultivars widely grown in Saudi Arabia. The main objective of this study was to investigate genetic diversity among 10 potato cultivars introduced from The Netherlands using morphological markers and RAPD markers.

\section{Materials and Methods}

\section{Plant materials and experimental design}

This study was conducted at the Experimental Farm of the College of Agriculture and Veterinary Medicine, Al-Qassim University during 2003 and 2004 fall seasons. The soil type of this farm is classified as a sandy soil. Data in Table 1 show specific soil characteristics.

The irrigation water has a $\mathrm{pH}=7.12$ and $990 \mathrm{ppm}$ total soluble salts. Drip irrigation was used and the amount of $12 \mathrm{~mm}$ of irrigation water was applied every other day throughout the two growing seasons.

Each treatment was represented with three replicates and arranged in a randomized complete block design. The plot area was $3 \times 6 \mathrm{~m}$ and contained 4 rows $75 \mathrm{~cm}$ apart. The planting distance was 30 $\mathrm{cm}$ within the row and presprouted tubers of Citrix, Kawalic, Aboulx, Spunta, Mondial, Victoria, Safaren, Edward, Etfadoal and Frizia cultivars were used. 
Table 1. The soil mechanical features at the experimental site.

\begin{tabular}{ccccccc}
\hline \multicolumn{2}{c}{$\begin{array}{c}\text { Mechanical } \\
\text { Analysis }\end{array}$} & $\begin{array}{c}\text { Bulk } \\
\text { Density } \\
\left(\mathrm{g} / \mathrm{cm}^{3}\right)\end{array}$ & $\begin{array}{c}\text { Water } \\
\text { Holding } \\
\text { Capacity } \\
(\%)\end{array}$ & $\begin{array}{c}\text { Field } \\
\text { Capacity } \\
(\%)\end{array}$ & $\begin{array}{c}\text { Wilting } \\
\text { Point } \\
(\%)\end{array}$ \\
$\begin{array}{c}\text { Sand } \\
(\%)\end{array}$ & $\begin{array}{c}\text { Silt } \\
(\%)\end{array}$ & $\begin{array}{c}\text { Clay } \\
(\%)\end{array}$ & & & & \\
\hline 96.3 & 1.8 & 1.9 & 1.501 & 17.17 & 9.6 & 4.35 \\
\hline
\end{tabular}

These potato cultivars were introduced from HZPC Holland B.V., The Netherlands. The origin of potato cultivars is listed in Table 2.

Planting dates of experiments 1 and 2 were $13^{\text {th }}$ of October 2002 and $10^{\text {th }}$ of October 2003, respectively. The plants in experiment 1 and 2 were harvested on $30^{\text {th }}$ of January 2003 and on $1^{\text {st }}$ of February 2004, respectively. A series of growth and yield parameters were measured and the data were statistically analyzed by the analysis of variance using the SAS package. Comparison of treatment means was performed by Duncan's multiple range test at the $\mathrm{P}=0.05$ level of significance. Data were analyzed according to Sendecor and Cochran (1980).

\section{Measurements}

Vegetative growth parameters: Three plants were randomly chosen 50 days after the planting date in 2002 and 2003 seasons, respectively, for recording the vegetative growth parameters, which included leaf area of the fifth upper leaf measured at fully expanded mature stage $\left(\mathrm{cm}^{2}\right)$ using a leaf area meter, model LI1300 Portable Area Meter (Stander Technique No.5, USA), and also leaf dry weight (g).

Total chlorophyll: Chlorophyll pigment was measured of the fifth upper leaf using a Minolta chlorophyll Meter SPAD -501.

Potato tuber yield: The number and weight of marketable tubers as well as total yield were recorded. Only tubers sized 20-55 $\mathrm{mm}$ in diameter were considered marketable tubers.

Quality of potato tubers: Specific gravity was measured directly after harvesting by choosing 15 marketable tubers randomly, and was calculated as follows:

$$
\mathrm{SG}=\frac{\text { Weight of tuber in air }}{\text { (Weight in air) - (Weight in water) }}
$$

\section{RAPD-PCR amplification}

Total genomic DNA of potato cultivars was extracted using the method described by Saghai-Maroof et al., (1984) for RAPD analysis. Twenty random primers were obtained from Operon Technology, USA. RAPD analysis was conducted in a thermal cycler (Thermolyne Amplitron). The reaction mixture (25 $\mu \mathrm{L})$ contained 1x PCR buffer with $\mathrm{Mg} \mathrm{Cl}_{2}(50 \mathrm{mM}$ $\mathrm{K} \mathrm{Cl}, 10 \mathrm{mM}$ Tris- $\mathrm{HCl}$ ( $\mathrm{pH}$ 9.0), $2 \mathrm{mM} \mathrm{Mg} \mathrm{Cl}$ and Triton X-100), $200 \mu \mathrm{M}$ each of dATP, dCTP, dGTP, and dTTP, 30 ng template DNA, $50 \mathrm{pM}$ of oligonucleotide primer and 1.5 unit of Taq polymerase. The mixtures were subjected to the following conditions: hold at $94^{\circ} \mathrm{C}$ for $2 \mathrm{~min}$, followed by 40 cycles of $94^{\circ} \mathrm{C}$ for 1 min, $36^{\circ} \mathrm{C}$ for $1 \mathrm{~min}$ and $72^{\circ} \mathrm{C}$ for $2 \mathrm{~min}$, and a final hold at $72^{\circ} \mathrm{C}$ for $5 \mathrm{~min}$. PCR products were visualized along with a DNA marker on $2 \%$ agarose gel with $1 \mathrm{X}$ TAE buffer and detected by staining with ethidium bromide. Gels were photographed on Polaroid films under UV light.

\section{Data handling and cluster analysis}

Data were scored for computer analysis on the basis of the presence or absence of the amplified products for each random primer. Basically, if a product was present in a genotype, it was designated "1", but if absent it was designated "0" after excluding irreproducible bands. Pair-wise comparisons of cultivars, based on the presence or absence of unique and shared polymorphic products, were used to generate similarity coefficients based on a simple matching. The similarity coefficients were then used to construct a dendogram by UPGMA

Table 2. The origin of potato cultivars.

\begin{tabular}{ll}
\hline Cultivars & Parents \\
\hline Citrix & Cardinal X SVP 709 \\
Kawalic & Astarte X SVP AM 66-42 \\
Aboulx & Ostara X Renska \\
Spunta & Bea X USDA X 96-56 \\
Mondial & Spunta X SVP VE 66295 \\
Victoria & Agria X Ropta J861 \\
Safaren & Fanettex X [Maris piper X INRA 67.86.37] \\
Edward & Primura X Alcmria \\
Etfadoal & Monalisa X Hudson \\
Frizia & ZPC 69L 160 X AM 66-42 \\
\hline
\end{tabular}


Table 3. Chlorophyll content (Spad), leaf area and leaf dry weight of ten potato cultivars in two successive seasons.

\begin{tabular}{|c|c|c|c|c|c|c|}
\hline \multirow{2}{*}{ Cultivars } & \multicolumn{2}{|c|}{ Chlorophyll Content } & \multicolumn{2}{|c|}{ Leaf Area $\left(\mathrm{cm}^{2}\right)$} & \multicolumn{2}{|c|}{ Leaf Dry Weight (g) } \\
\hline & $2002 / 2003$ & $2003 / 2004$ & $2002 / 2003$ & $2003 / 2004$ & $2002 / 2003$ & $2003 / 2004$ \\
\hline Citrix & 38.53 & 38.26 & 44.97 & 44.26 & 0.26 & 0.29 \\
\hline Kawalic & 41.56 & 41.03 & 53.00 & 52.56 & 0.54 & 0.55 \\
\hline Aboulx & 34.10 & 33.93 & 41.46 & 42.83 & 0.60 & 0.58 \\
\hline Spunta & 37.63 & 36.43 & 54.51 & 51.90 & 0.35 & 0.30 \\
\hline Mondial & 38.30 & 37.86 & 70.94 & 67.73 & 0.75 & 0.61 \\
\hline Victoria & 45.16 & 40.76 & 53.20 & 54.96 & 0.41 & 0.38 \\
\hline Safaren & 42.36 & 41.40 & 71.48 & 74.20 & 0.62 & 0.61 \\
\hline Edward & 40.20 & 40.13 & 39.83 & 37.40 & 0.43 & 0.48 \\
\hline Etfadoal & 38.90 & 39.43 & 52.55 & 53.56 & 0.53 & 0.59 \\
\hline Frizia & 44.36 & 42.03 & 60.01 & 53.56 & 0.47 & 0.47 \\
\hline L.S.D at $5 \%$ & 2.061 & 1.667 & 4.717 & 5.242 & 0.05 & 0.04 \\
\hline
\end{tabular}

(Unweighted Pair-Group Method with Arithmetical Averages) using NTSYS-PC (Rohlf, 2000).

\section{Results and Discussion}

\section{Morphological characters}

Total chlorophyll and vegetative growth: It is evident from Table 3 that cultivars Victoria, Frizia, and Safaren resulted in highest chlorophyll content compared to the other cultivars in both seasons. The lowest chlorophyll content was produced by cv. Aboulx in both seasons. The leaf area and leaf dry weight varied considerably among the different potato cultivars (Table 3). The highest leaf area was produced by Safaren and Mondial in both seasons. Cultivars Victoria and Kawalic had a lower leaf area than cultivars Safaren and Mondial and higher than cultivars Edward and Aboulx. Moreover, cultivars Safaren and Mondial had the highest leaf dry weight in both seasons. On the other hand, cultivar Citrix had the lowest leaf dry weight in both seasons. These results could reflect the variation of vegetative growth and development among the different studied potato cultivars. Similar trends of variation in potato plant development and its reflection on potato yield was observed by Tibbits et al. (1992), Al-Moshileh and Motawei (2001) and Al-Moshileh et al. (2003).

Tuber yield and specific gravity: Data in Table 4 clearly indicates that cultivars Aboulx and Mondial produced the highest tuber yield in both seasons. These two cultivars were followed by Spunta, Etafadoal, and Frizia in both seasons. On the other hand, cultivars Victoria and Edward were characterized by considerably lower yield production than the other studied cultivars.

Table 4 indicates that specific gravity varied greatly among the different potato cultivars. Aboulx, Kawalic, and Mondial cultivars gave the highest specific gravity in both seasons. These cultivars, except cultivar Kawalic, were also characterized by the highest tuber yield. Cultivars Spunta and Frizia gave the lowest specific gravity.

In spite of the importance of the photosynthesis process, formation of carbohydrates and translocation to the tubers, tuber yield did not exactly reflect the vegetative growth. This phenomenon could indicate that yield in potatoes in this study may not only

Table 4. Marketable yield and specific gravity of ten potato cultivars in two successive seasons.

\begin{tabular}{lrrrrr}
\hline & \multicolumn{3}{c}{$\begin{array}{c}\text { Marketable Yield } \\
\left(\mathrm{g} / \mathrm{m}^{2}\right)\end{array}$} & & \multicolumn{2}{c}{$\begin{array}{c}\text { Specific Gravity } \\
\text { Units } \\
\left(\mathrm{g} / \mathrm{cm}^{-3}\right)\end{array}$} \\
\cline { 2 - 3 } \cline { 5 - 6 } Cultivars & $2002 /$ & $2003 /$ & & $2002 /$ & $2003 /$ \\
& 2003 & 2004 & & 2003 & 2004 \\
\hline Citrix & 493.96 & 548.36 & & 1.080 & 1.080 \\
Kawalic & 595.03 & 660.23 & & 1.120 & 1.130 \\
Aboulx & 790.33 & 877.73 & & 1.140 & 1.130 \\
Spunta & 687.73 & 763.30 & & 1.070 & 1.060 \\
Mondial & 762.16 & 846.30 & & 1.110 & 1.120 \\
Victoria & 384.26 & 469.50 & & 1.080 & 1.090 \\
Safaren & 656.56 & 729.33 & & 1.070 & 1.070 \\
Edward & 431.83 & 476.63 & & 1.091 & 1.090 \\
Etfadoal & 670.30 & 740.73 & & 1.111 & 1.110 \\
Frizia & 657.33 & 738.73 & & 1.041 & 1.040 \\
L.S.D at 5\% & 15.52 & 15.48 & 0.350 & 0.048 \\
\cline { 5 - 6 } & & & &
\end{tabular}


Table 5. The 12 selected Operon primers and the number of amplified products and polymorphic fragments.

\begin{tabular}{llcc}
\hline Primers & Sequence 5' to 3' & $\begin{array}{c}\text { Ampli- } \\
\text { fied } \\
\text { Products }\end{array}$ & $\begin{array}{c}\text { Poly- } \\
\text { morphic } \\
\text { Fragments }\end{array}$ \\
\hline OP-A05 & AGGGGTCTTG & 6 & 3 \\
OP-A07 & GAAACGGGTG & 5 & 4 \\
OP-A08 & GTGACGTAGG & 8 & 6 \\
OP-A09 & GGGTAACGCC & 7 & 4 \\
OP-A11 & CAATCGCCGT & 7 & 6 \\
OP-A12 & TCGGCGATAG & 6 & 4 \\
OP-A14 & TCTGTGCTGG & 3 & 1 \\
OP-A15 & TTCCGAACCC & 7 & 5 \\
OP-A16 & AGCCAGCGAA & 4 & 3 \\
OP-A17 & GACCGCTTGT & 4 & 2 \\
OP-A18 & AGGTGACCGT & 4 & 3 \\
OP-A19 & CAAACGTCGG & 8 & 5 \\
OP-A20 & GTTGCGATCC & 6 & 4 \\
\hline
\end{tabular}

depend on leaf area and vegetative growth, but also on genotype and possibly other environmental factors (Al-Moshileh, 2001).

\section{RAPD analysis}

In the RAPD marker analysis, the selected primers OPA05,OPA07, OPA08, OPA09, OPA11, OPA12, OPA14, OPA15, OPA16, OPA17, OPA18, OPA19, and OPA20, generated 75 amplified products, with fragment numbers varying from 3 (OPA14) to 8 (OPA08 and OPA19) (Table 5), 50 of which were polymorphic. Examples of polymorphism are shown in Figure 1. By means of the 13 RAPD markers, all cultivars were identified and separated. Collares et al. (2004) identified 27 potato genotypes using only four RAPD primers. Demeke et al. (1993), using the RAPD technique with only two primers, identified 36 commercial potato cultivars. According to these authors, specific primers seem to produce more fragments and more DNA amplified polymorphisms and are, therefore, adequate for identifying potato cultivars by the RAPD technique. Ghislain et al. (1999), using 12 primers, obtained 102 polymorphic
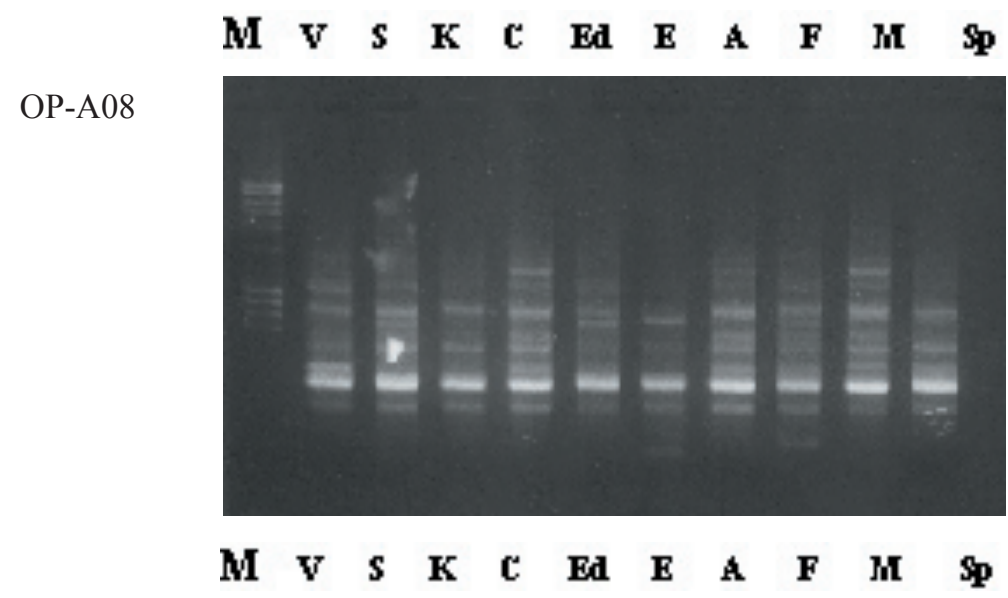

OP-A17

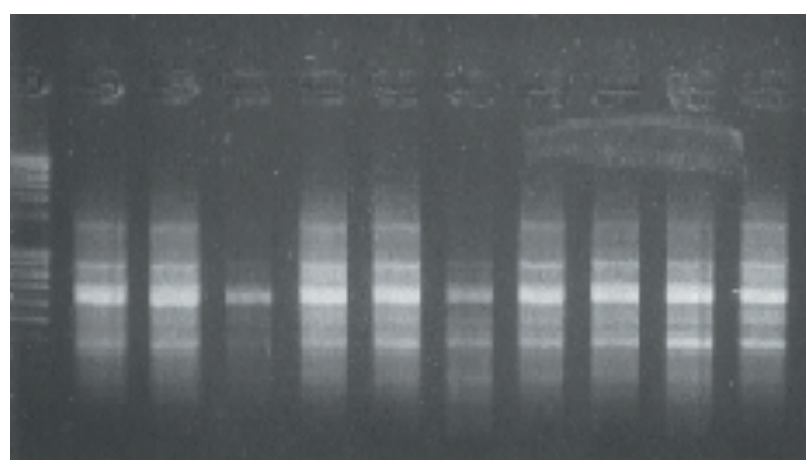

Figure 1. Polymorphism revealed using primers OP-A08 and OP-A17 to amplify genomic DNA purified from 10 potato cultivars. 
Table 6. Simple matching coefficients of similarity determined from analysis using 75 RAPD loci.

\begin{tabular}{|c|c|c|c|c|c|c|c|c|c|c|c|}
\hline Cultivars & & V & $\mathrm{S}$ & K & C & Ed & E & A & $\mathrm{F}$ & M & $\mathrm{Sp}$ \\
\hline Victoria & (V) & 1.00 & & & & & & & & & \\
\hline Safaren & (S) & 0.69 & 1.00 & & & & & & & & \\
\hline Kawalic & (K) & 0.69 & 0.63 & 1.00 & & & & & & & \\
\hline Citrix & (C) & 0.70 & 0.81 & 0.64 & 1.00 & & & & & & \\
\hline Edward & (Ed) & 0.69 & 0.81 & 0.69 & 0.75 & 1.00 & & & & & \\
\hline Etfadoal & (E) & 0.50 & 0.50 & 0.63 & 0.52 & 0.57 & 1.00 & & & & \\
\hline Aboulx & (A) & 0.69 & 0.73 & 0.65 & 0.77 & 0.68 & 0.50 & 1.00 & & & \\
\hline Frizia & (F) & 0.67 & 0.69 & 0.69 & 0.70 & 0.72 & 0.67 & 0.69 & 1.00 & & \\
\hline Mondial & (M) & 0.71 & 0.88 & 0.62 & 0.92 & 0.77 & 0.50 & 0.81 & 0.72 & 1.00 & \\
\hline Spunta & $(\mathrm{Sp})$ & 0.61 & 0.81 & 0.69 & 0.78 & 0.75 & 0.57 & 0.74 & 0.79 & 0.83 & 1.00 \\
\hline
\end{tabular}

markers and could discriminate 128 accessions of potato.

The similarity analysis based on RAPD markers showed that cultivars Victoria and Etfadoal presented the least similarity $(0.50)$, whereas cultivars Mondial and Citrix had the greatest similarity (0.92) (Table $6)$. The high value of genetic similarity obtained between Mondial and Spunta (0.81) may be due to the fact that Spunta was one of the parents of cultivar Mondial (Spunta $\times$ SVP VE66295). On the other hand, cultivar Etfadoal had the greatest genetic diversity of all cultivars. These data revealed broad variability among potato cultivars. Sun et al. (2003) found genetic similarity coefficients varied from 0.29 to 0.90 among cultivated potato hybrids.

Cluster analysis was conducted to generate a dendogram elucidating relationships among potato cultivars. The dendogram constructed with UPGMA analysis revealed three clusters (Fig. 2). Cluster I contained cultivars Victorial and Kawalic. Custer II contained cultivars Safaren, Citrix, Mondial, Spunta, Edward, Aboulx and Frizia. Cluster III contained cultivar Etafadoal. Hosaka et al. (1994), studying the genetic relations of 73 Japanese potato cultivars, reported that the patterns of RAPD banding of closely related cultivars were grouped. Taylor and Ford (1997) were able, by means of RAPD technique, to

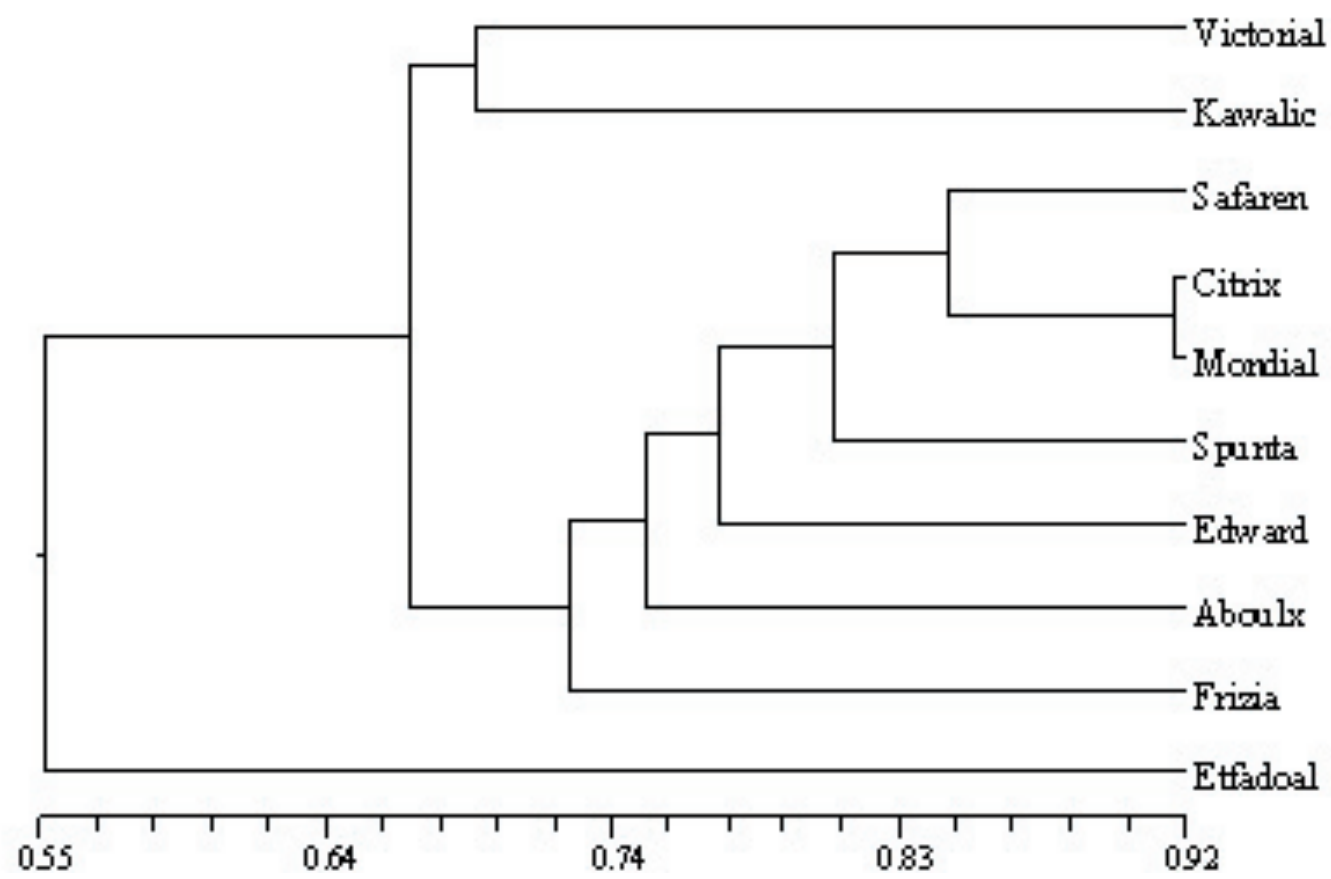

Figure 2. Dendrogram constructed from similarity coefficients showing the clustering of potato cultivars. 
differentiate closely related potato cultivars, which was not possible by morphological techniques. Forapani et al. (1999), Polzrova and Ptacek (2000), and Isenegger et al. (2001) considered RAPD markers a fast technique for characterizing and identifying cultivars and for differentiating and estimating relationships.

Our results have demonstrated that it is possible to distinguish potato cultivars using RAPD technique, which provides a better evaluation of genetic divergence than morphological characters.

\section{References}

Al-Moshileh, A.M. 2001. Evaluation of 24 potato cultivars under central Saudi Arabia conditions. Bulletin of the Faculty of Agriculture, University of Cairo. 52:141-150.

Al-Moshileh, A.M. and M.I. Motawei. 2001. Effect of light intensity levels on potato productivity under Al-Qassim environmental conditions. Alexandria University. Faculty of Agriculture, Saba-Basha Journal of the Advances in Agricultural Research 6:87-93.

Al-Moshileh, A.M., M.Z. El-Shinnawi and M.I. Motawei. 2003. Effect of shading by date palm leaves on growth and yield of potato under different irrigation levels. Egypt Journal of Horticulture 30:253-265.

Caetano-Anolles, G., B.J. Bassam and P.M. Bresshoff. 1991. DNA amplification fingerprinting: A strategy for genome analysis. Plant Molecular Biology Reporter 9:294-307.

Collares, E.A.S., E. Choer and A. da S. Pereira. 2004. Characterization of potato genotypes using molecular markers. Pesquisa Agropecuaria Brasileira 39: 1-11.

Coumou, D. 2000. Netherlands Catalogue of Potato Varieties. The Netherlands Consultative Potato Institute. $2502 \mathrm{CH}$, Den Haag. The Netherlands. 255pp.

Del Rio, A.H., J.B. Bamberg, Z. Huaman, A. Salas and S.E. Vega. 2001. Association of ecogeographical variables and RAPD marker variation in wild potato populations of the USA. Crop Science 41: 870-878.

Demeke, T., L.M. Kawchuc and D.R. Lynch. 1993. Identification of potato cultivars and clonal variants by random amplified polymorphic DNA analysis. American Potato Journal 70:561-570.
Dos Santos, J.B., J. Nienhuis, P.W. Skorch, J. Tivang and M.K. Slocum. 1994. Comparison of RAPD and RFLP genetic markers in determining genetic similarity among Brassica oleracea L. genotypes. Theoretical and Applied Genetics 87:909-915.

Forapani, S., A. Carboni, E. Castellani, G. Mondolino and P. Ranalli. 1999. RAPD markers for potato germplasm characterization. Journal of Genetics and Breeding 53: 143-147.

Ghislain, M., D. Zhang, D. Fajardo, Z. Huaman, and R.J. Hijmans. 1999. Marker-assisted sampling of the cultivated Andean potato Solanum phureja collection using RAPD markers. Genetic Resources and Crop Evaluation. 46: 547-555.

Hallden, C., N.O. Nilsson, I.M. Rading and T. Sall. 1994. Evaluation of RAPD and RFLP markers in comparison of Brassica napus breeding lines. Theoretical and Applied Genetics 88:123-128.

Hosaka, K., M. Mori and K. Ogawa. 1994. Genetic relationships of Japanese potato cultivars assessed by RAPD analysis. American Potato Journal. 71: 535-546.

Isenegger, D.A., P.W.J. Taylor, R. Ford, P. Franz, G.R. McGregor and J.F. Hutchinson. 2001. DNA fingerprint and genetic relationships of potato cultivars (Solanum tuberosum L.) commercially grown in Australia. Australian Journal of Agricultural Research 52:911-918.

Joyce, S.M., P. Vanughan, T.V. McCarthy and A.C. Cassells. 1999. PCR analysis of bisulfite-modified DNA to investigate developmental variation in micropropagated potatoes (Solanum tuberosum L.). Potato Research 42:546-558.

Ministry of Agriculture. 2004. Indicators for agriculture in Kingdom of Saudi Arabia. 17 $7^{\text {th }}$ issue.

Nybom, H. 1994. DNA [sic] fingerprinting- A useful tool in fruit breeding. Euphytica 77:59-64.

Polzerova, H. and J. Ptacek. 2000. Detection of DNA polymorphism in potato cultivar using RAPD technique. Czech Journal of Genetic and Plant Breeding 36:11-15.

Rocha, B.H.G., E. Augustin, A.da S. Pereira, G.R. de L. Fortes and J.A. Peters. 2002. Caracterizacao de cultivares de batata atraves de marcadores moleculares. Revista Cientifica Rural 7:42-51.

Rohlf, F.J. 2000. NTSYSpc numerical taxonomy and multivariate analysis system, Version 2.1 User Guide. Exeter Software, Setauket, N.Y. 
Saghai-Maroof, M.A., R.M. Biyashev, G.P. Yang, Q. Zhang and R.W. Allard. 1984. Extraordinarily polymorphic microsatellite DNA in barley: species diversity, chromosomal locations, and population dynamics. Proceedings of the National Academy of Sciences, USA. 91:5466-5470.

Schneider, K. and D.S. Douches. 1997. Assessment of PCR-based simple sequencing repeats to fingerprint North American potato cultivars. American Potato Journal 74:149-160.

Smith, J.S.C. and O.S. Smith. 1992. Fingerprinting crop varieties. Advances in Agronomy 47:85-140.

Snedecor, G.W. and W.G. Cochran (1980). Statistical methods. Sixth Edition, Iowa State University Press, Ames, Iowa.

Sun, G., G. Wang-Pruski, M. Mayich and H. Jong. 2003. RAPD and pedigree-based genetic diversity estimates in cultivated diploid potato hybrids. Theoretical and Applied Genetics 107: 110-115.

Taylor, P.W.J. and R. Ford. 1997. The application of RAPD markers for potato cultivar identification.
Australian Journal of Agricultural Research. 48: 1213-1218.

Tibbitts, T.W., W. Cao and S.M. Bennet. 1992. Utilization of potatoes for life support in space. V-Evaluation of cultivars in response to continuous light and high temperature. American Potato Journal 69:229-237.

Williams, C.E. and D.A. St. Clair. 1993. Phonetics relationships and levels of variability detected by restriction fragment length polymorphism and random amplified polymorphic DNA analysis of cultivated and wild accessions of Lycopersicon esculentum. Genome 36:619-630.

Wilkie, S.E., P.G. Isaac and R.J. Slater. 1993. Random amplified polymorphic DNA (RAPD) markers for genetic analysis in Allium. Theoretical and Applied Genetics 86:497-504.

Zaag, D.E. 1991. The Potato Crop in Saudi Arabia. Saudi Potato Development Programme. Ministry of Agriculture and Water. Riyadh. Saudi Arabia.

Received: March 2005

Accepted: April 2007 